\title{
Effect of Stress on Irradiation-induced Creep and Swelling of Fe-18Cr-10Ni-Ti Steel Pressurized Specimens Irradiated in the BOR-60 Reactor
}

\section{Evgenii Makarov, Victor Neustroev, Sergey Belozerov, Dmitrii Markelov, and Aleksandr Obukhov}

JSC "State Scientific Center - Research Institute of Atomic Reactors", Dimitrovgrad, Russia

\section{Abstract}

The paper presents the data on the effect of stress of various signs on the irradiationinduced creep strain and swelling of austenitic $\mathrm{Fe}-18 \mathrm{Cr}-10 \mathrm{Ni}-\mathrm{Ti}$ steel pressurized specimens. The pressurized specimens of standard and contoured geometry were irradiated in the BOR-60 reactor up to the damage dose of 90 and $36 \mathrm{dpa}$, accordingly,

Corresponding Author: Victor Neustroev neustroev@niiar.ru

Received: 21 December 2017

Accepted: 15 April 2018

Published: 6 May 2018

Publishing services provided by Knowledge $\mathrm{E}$

(c) Evgenii Makarov et al. This article is distributed under the terms of the Creative Commons Attribution License, which permits unrestricted use and redistribution provided that the original author and source are credited.

Selection and Peer-review under the responsibility of the MIE-2017 Conference Committee.

\section{G OPEN ACCESS}

\section{INTRODUCTION}

The work to justify both the possible service-life extension of the internals from operated VVER-1000 reactors and performance of internals materials from new VVER reactors up to 60 years is rather relevant to the present day. Areas with tensile and compression stresses can appear in the contoured internals with a large number of orifices for cooling under the temperature gradients. It is therefore important to investigate the effect of stress on the material properties and structure. To perform the investigations, the austenitic Fe-18Cr-10Ni-Ti steel was chosen as the internals material of VVER reactors under both operation and development.

The work to investigate the effect of tensile stress on the material properties and structure has already been performed in RIAR, Russia and abroad, but the effect of compression stress has been studied negligibly [1-5]. Several articles devoted to the problem [5-7] exist, but the results provided need additional confirmation.

Therefore, the purpose of this work is to experimentally determine the effect of stress on the irradiation-induced swelling and creep strain in $\mathrm{Fe}-18 \mathrm{C} r-10 \mathrm{Ni}-\mathrm{Ti}$ austenitic 
steels as well as on the steel microstructure under neutron irradiation in the BOR-60 fast reactor.

\section{MATERIALS AND EXPERIMENTAL METHODS}

The pressurized contoured specimens made of Fe-18Cr-10Ni-Ti steel were irradiated in the BOR-60 reactor up to a damage dose of $36 \mathrm{dpa}$ and standard specimens were irradiated up to $90 \mathrm{dpa}$ at a temperature not exceeding $350^{\circ} \mathrm{C}$ [8]. Compression and tensile stresses were simultaneously applied to the claddings of irradiated specimens of the contoured geometry. No-stress specimens were irradiated at the same time as the above ones. In this study, we used the TEM methods to investigate the structure of the material and measure linear dimensions of the pressurized specimens in order to determine the irradiation-induced creep strain and swelling. TEM investigations of the steel microstructure were done using the co-axial pressurized specimens irradiated in the BOR-60 reactor up to a damage dose of $36 \mathrm{dpa}$ at temperatures of 340 and $420^{\circ} \mathrm{C}$.

\section{RESULTS AND DISCUSSION}

\subsection{Investigations results related to austenitic $08 \mathrm{X}_{18 \mathrm{H}} 10 \mathrm{~T}$ steel standard pressurized specimens irradiated at a temperature of $340^{\circ} \mathrm{C}$ up to a damage dose of $\sim 90 \mathrm{dpa}$}

Based on the performed investigations and analysis results, the mechanisms of changes in the length and diameter of the pressurized specimens were verified. It is shown (Fig. 1) that the length and diameter of the pressurized specimens grow proportionally with the damage dose growth under various levels of stress applied. The dependence between the relative diameter increment in the $\mathrm{Fe}-18 \mathrm{Cr}-10 \mathrm{Ni}$-Ti steel pressurized specimens and the stress and damage dose is close to linear.

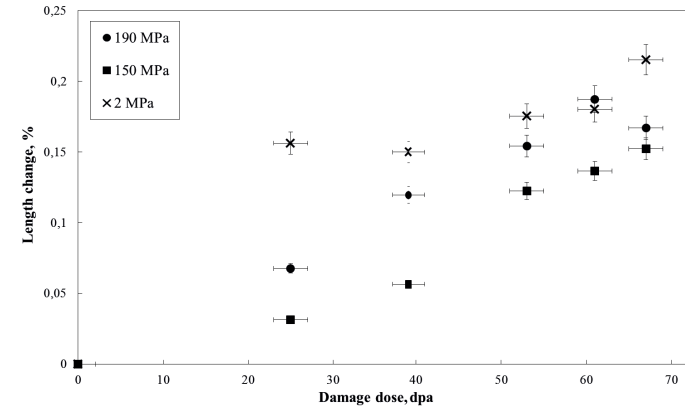

a)

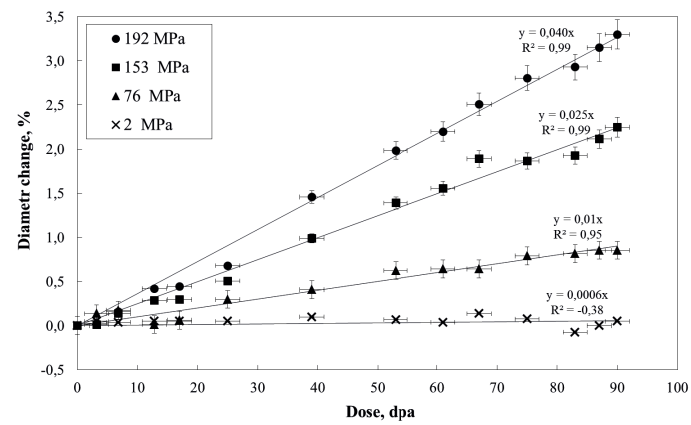

b)

Figure 1: Dose-length (a) and dose-diameter (b) dependencies in the standard Fe-18Cr-10Ni-Ti steel pressurized specimens irradiated in the BOR-60 reactor at $340^{\circ} \mathrm{C}$, at various stress levels. 
The creep modulus calculation [9] shows that for the standard specimens with stresses 150-190 MPa irradiated in the BOR-60 reactor, it tends to a certain level of saturation of about $2.0 \cdot 10^{-6}(\mathrm{MPa} \cdot \mathrm{dpa})^{-1}$ at a damage dose higher than $40 \mathrm{dpa}$ and irradiation temperature of $340^{\circ} \mathrm{C}$.

\subsection{Investigations results related to austenitic $\mathrm{Fe}-18 \mathrm{Cr}-10 \mathrm{Ni}-\mathrm{Ti}$ steel co-axial pressurized specimens irradiated at a temperature of $420^{\circ} \mathrm{C}$ up to a damage dose of $\sim 36 \mathrm{dpa}$}

The specimens were located in one of the levels of the BOR-60 irradiation rig suspension. During the reactor outages, the diameter and length of the specimens were measured. The measurements were done in the BOR-6o hot cell using contact methods having the length measurement error of $\pm 10 \mu \mathrm{m}$ and diameter measurement error of $\pm 5 \mu \mathrm{m}$.

The investigations and further analysis of the results proved the earlier obtained dose dependencies for changes in the length and diameter of the pressurized specimens. It was shown that as the damage dose became higher, the length and diameter of the pressurized specimens grew as well under different stresses applied. The dependence between the increment in the diameter of the Fe-18Cr-10Ni-Ti steel contoured specimens and the damage dose was close to linear.

The creep modulus was calculated to be equal to $2.0 \cdot 10^{-6}(\mathrm{MPa} \cdot \mathrm{dpa})^{-1}$ at $\mathrm{T}_{\text {irr. }}$. $=340^{\circ} \mathrm{C}$ that corresponds to the creep modules of other austenitic steels at the said temperatures.

\subsection{Investigations results related to} austenitic Fe-18Cr-10Ni-Ti steel co-axial pressurized specimens irradiated at a temperature of $340^{\circ} \mathrm{C}$ up to a damage dose of $\sim 36 \mathrm{dpa}$

The pressurized contoured specimens made of $\mathrm{Fe}-18 \mathrm{Cr}$-10 Ni-Ti steel were irradiated in the BOR-60 reactor up to a damage dose of $36 \mathrm{dpa}$ at $\sim 420^{\circ} \mathrm{C}$. Compression and tensile stresses were simultaneously applied to the claddings of irradiated specimens. No-stress specimens were irradiated at the same time as the above ones.

The experiment and analysis of the results proved the earlier obtained dose dependencies for changes in the length and diameter of the pressurized specimens. It is 
shown (Fig.2) that as the damage dose became higher, the length and diameter of the pressurized specimens grew as well under different stresses applied.

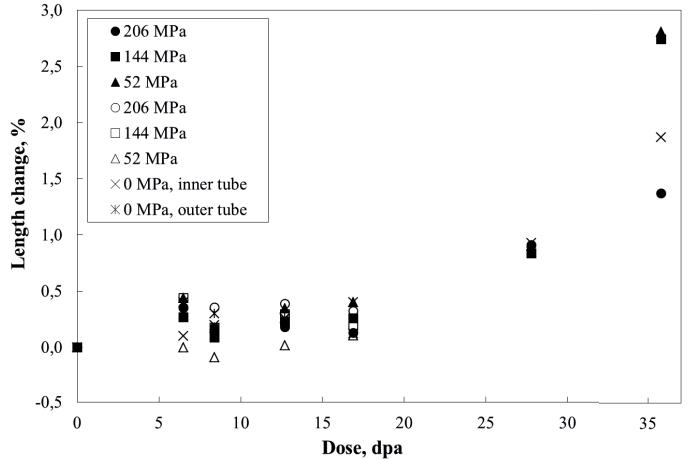

a)

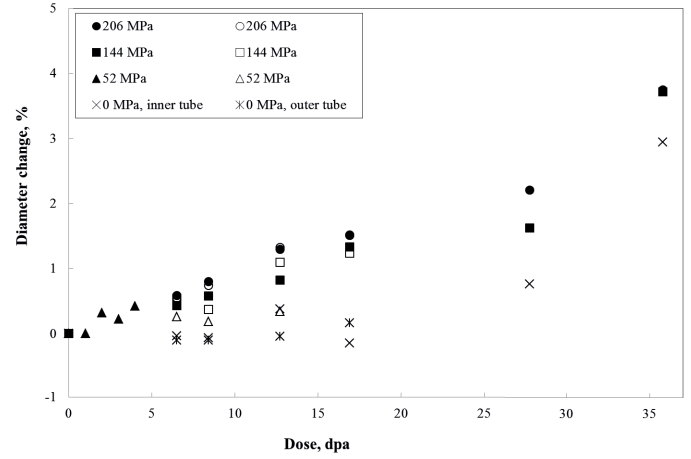

b)

Figure 2: Dose-length (a) and dose-diameter (b) dependencies in the Fe-18Cr-10Ni-Ti steel co-axial pressurized specimens irradiated in the BOR-60 reactor up to $36 \mathrm{dpa}$ at $420^{\circ} \mathrm{C}$.

\subsection{Examination of the microstructure of irradiated $\mathrm{Fe}-18 \mathrm{Cr}-10 \mathrm{Ni}$-Ti steel pressurized specimens}

The TEM microscope JEM-2000FXII was used to examine the microstructure of the pressurized specimens irradiated up to $36 \mathrm{dpa}$ at 420 and $340^{\circ} \mathrm{C}$.

\subsection{1. $420^{\circ} \mathrm{C}$}

TEM examination revealed the presence of similar constituents in the irradiated Fe$18 \mathrm{Cr}-10 \mathrm{Ni}$-Ti steel pressurized specimens, i.e. vacancies of different diameters and concentration, dislocation loops and secondary phase particles (Fig.3). The swelling and average void diameter rise in case of both compression and tensile stresses are applied (Fig.4). However, the voids concentration in the specimens did not change practically as both applied stresses became higher (Fig.5).

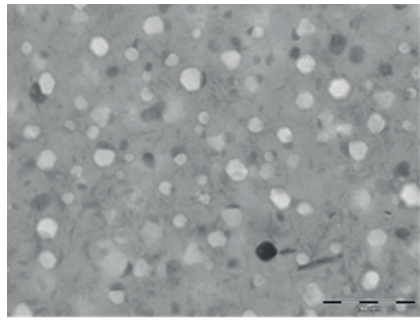

a)

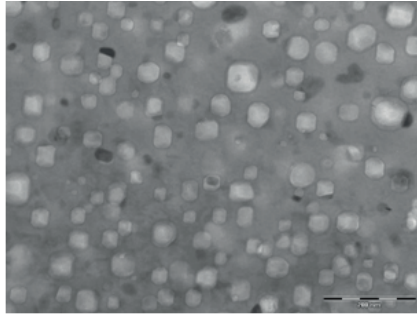

b)

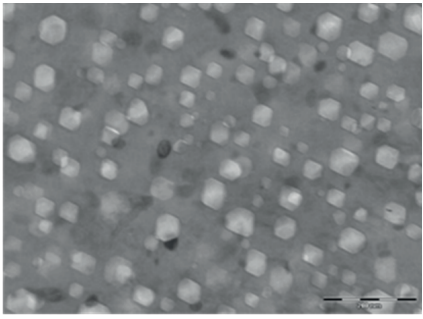

c)

Figure 3: Vacancies in the austenitic Fe-18Cr-10Ni-Ti specimens irradiated in the BOR-60 reactor up to $36 \mathrm{dpa}$ at $420^{\circ} \mathrm{C}$ : a) - no stress; b) - tensile tangential stress + $206 \mathrm{MPa}$; c) - compression tangential stress $-110 \mathrm{MPa}$. 


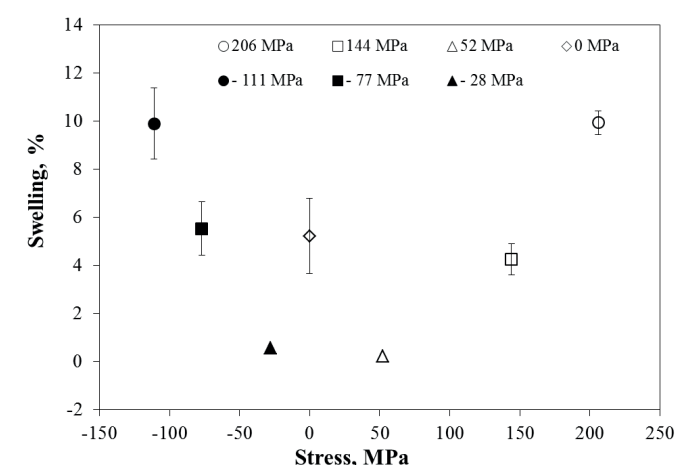

(a)

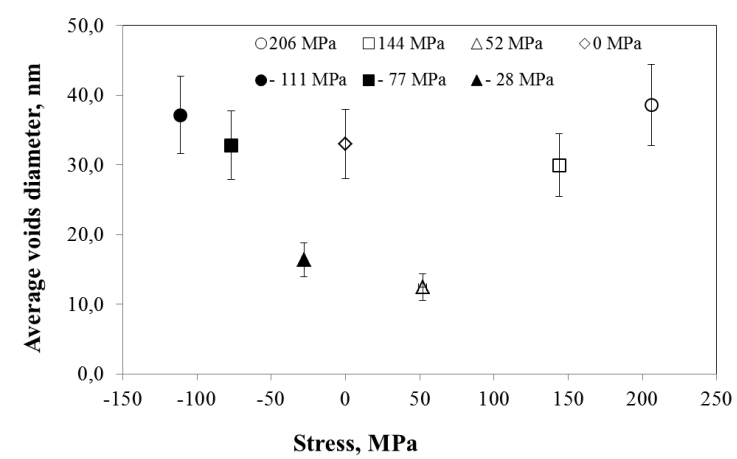

(b)

Figure 4: Voids swelling (a) and voids average diameter (b) vs. stress in Fe-18Cr-10Ni-Ti specimens irradiated up to $36 \mathrm{dpa}$.

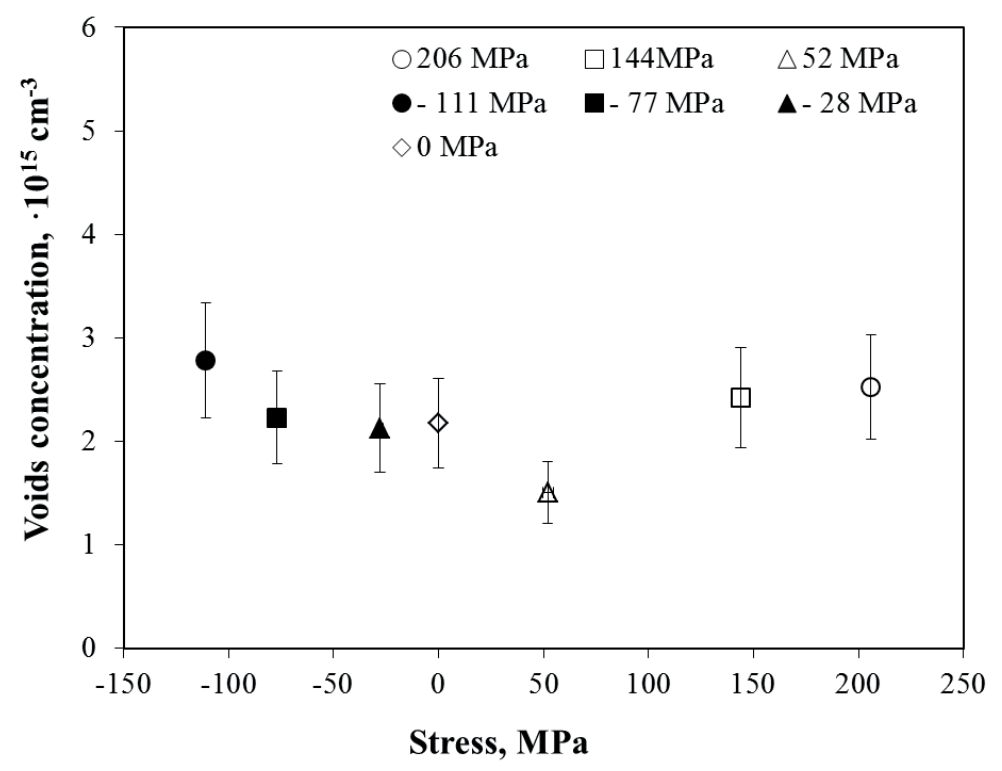

Figure 5: Voids concentration vs. stress in Fe-18Cr-10Ni-Ti specimens irradiated up to $36 \mathrm{dpa}$.

\subsection{2. $340^{\circ} \mathrm{C}$}

Since both irradiation temperature and damage dose for the specimens in question were the same, then the microstructure of all specimens was also practically the same. Equiaxial grains of austenite were observed in all specimens as well as secondary phase globular precipitates distributed uniformly in the material bulk. The globular precipitates are particles of titanium carbonitride $\mathrm{Ti}(\mathrm{C}, \mathrm{N})$ and can be found in this steel even in the initial state. The size of particles ranged from $0.1 \mu \mathrm{m}$ to $1.2 \mu \mathrm{m}$; their maximal concentration made up about $3 \times 10^{17} \mathrm{~m}^{-3}$. These particles can be found both in the grain body and at the inter-grain boundaries.

Single $\alpha$-Fe phase precipitates were found in a - 62 MPa specimen. Probably, this phase could be found in other specimens but it was not detected by the TEM because of 
its low concentration. No voids were found in the specimens. The dislocation structure is characterized by the presence of dislocation loops, in particular Frank loops (Fig.7).

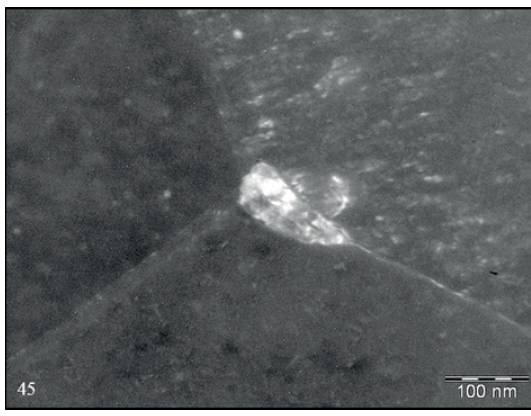

a)

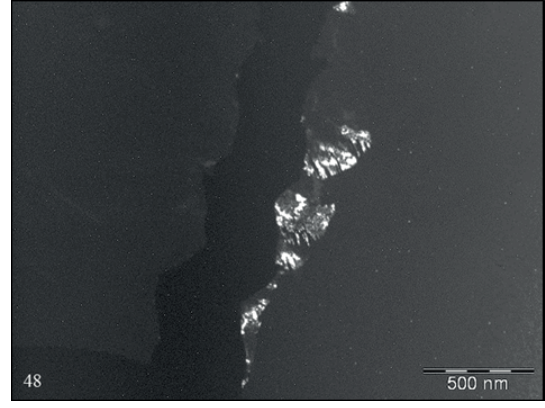

b)

Figure 6: Dark-field images of the $\alpha$-Fe phase precipitates in the - $62 \mathrm{MPa}$ specimen at the grain triboundary (a) and at the edge of a crack (b) appeared during the electrolytical thinning of the specimen.

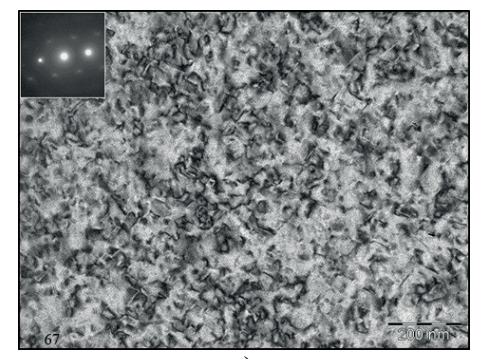

a)

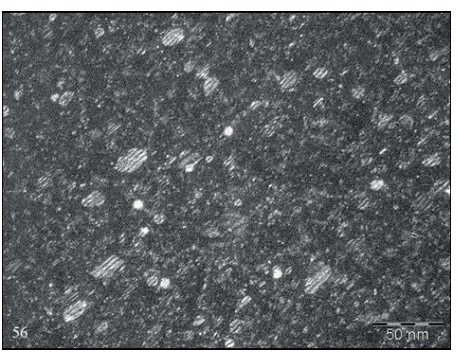

b)

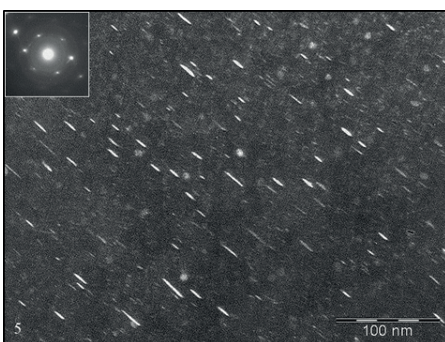

c)

Figure 7: Dislocation structure of specimens under investigation: (a) light-field image of dislocation loops in a + 82 MPa specimen; (b) dark-field image of the Frank loops in reflex [111] in a - 41 MPa specimen, (c) dark-field image of the Frank loops in reflex [111] band in + 247 MPa specimens.

It is clearly seen that as the stress modulus rises, the loop concentration in steel increases as well (Fig.8a). No dependence was reveled between the dislocation loop size and applied stress (Fig.8b).

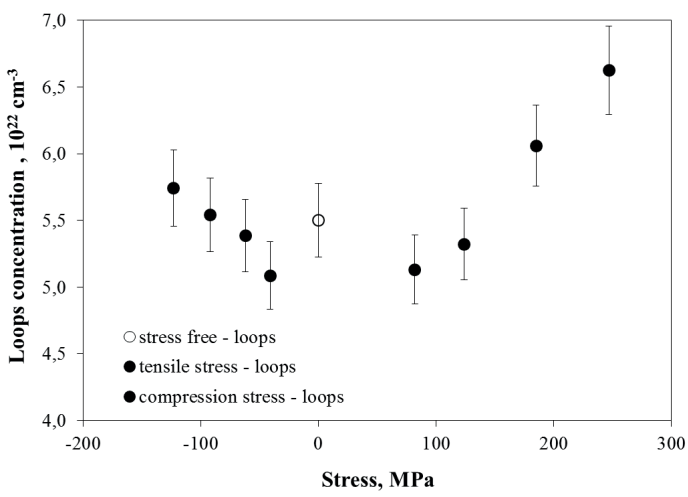

a)

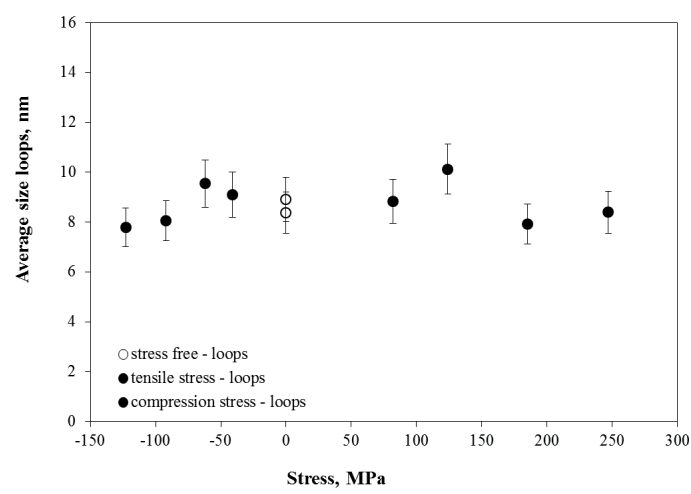

b)

Figure 8: Loop concentration (a) and average loop size (b) vs. stress in Fe-18Cr-10Ni-Ti steel specimens irradiated up to $36 \mathrm{dpa}$ at $\mathrm{T}_{\text {irr. }}=340^{\circ} \mathrm{C}$. 


\section{CONCLUSION}

The investigation of austenitic $\mathrm{Fe}-18 \mathrm{Cr}-10 \mathrm{Ni}$-Ti steel standard and co-axial pressurized specimens irradiated in the BOR-60 reactor showed the following:

1. The diameter and length of both types of pressurized specimens increase linearly as the damage dose rises;

2. The creep modules calculated for steel Fe-18Cr-10Ni-Ti are in good correlation with the creep modules of $18 \mathrm{Cr}$-9Ni-based austenitic steels;

3. TEM examinations showed a presence of vacancies in the corrosion-resistant austenitic $\mathrm{Fe}-18 \mathrm{Cr}-10 \mathrm{Ni}-\mathrm{Ti}$ pressurized specimens irradiated up to $36 \mathrm{dpa}$ at $420^{\circ} \mathrm{C}$. As both types of stresses applied rise, the swelling and average voids diameter change slightly;

4. No voids were reveled in the pressurized specimens irradiated up to $36 \mathrm{dpa}$ at $340^{\circ} \mathrm{C}$

5. Globular particles of titanium carbonitride as well as G-phase particles were revealed. Single $\alpha$-Fe phase precipitates were found in some specimens;

6. Dislocation Frank loops were revealed having an average diameter of about 9nm and concentration of up to $6.6 \cdot 10^{22} \mathrm{~m}^{-3}$.

7. No significant difference was revealed in the effect of both tensile and compression stresses on the microstructure of steel Fe-18Cr-10Ni-Ti specimens irradiated in the $\mathrm{BOR}-60$ at $340^{\circ} \mathrm{C}$;

8. The investigation results can be used to justify the prolongation of the VVER-1000 baffle lifetime and for new VVER-1200 projects as well.

\section{References}

[1] Shamardin V K, Neustroev V S, Golovanov V N et al 1990 Proc. 14th Int. Symp. (Philadelphia) vol 2 p 753-765

[2] Neustroev V S, Belozerov S V, Makarov E I, Ostrovsky Z E 2010 J. The Physics of Metals and Metallography 110 (4) 412-416

[3] Neustroev V S, Belozerov S V, Makarov E I, Obuhov A V 2014 J. The Physics of Metals and Metallography 115 (10) 1007-1011

[4] Neustroev V S, Ostrovsky Z E, Shamardin V K 1987 J. Nucl. Mater. 612-616 
[5] Lauritzen T, Vaidyananthan S et al 1987 Proc. 13th Int. Symp. "Radiation-Induced changes in Microstructure" 955 p. 101-103

[6] Hall Jr. M M 2010 J. Nucl. Mat. 396 112-118

[7] Hall Jr. M M, Flinn J E 2010 J. Nucl. Mat. 396 119-129

[8] Varivtsev A V and Zhemkov I Yu 2014 Physics of Atomic Nuclei 77 (14) 1664-1670

[9] Garner F A 1994 Materials Science and Technology: A Comprehensive Treatment 10A 419-543 